\title{
Copper, Llamas and a Virus
}

\section{A Tale of Historically Entangled Frontiers}

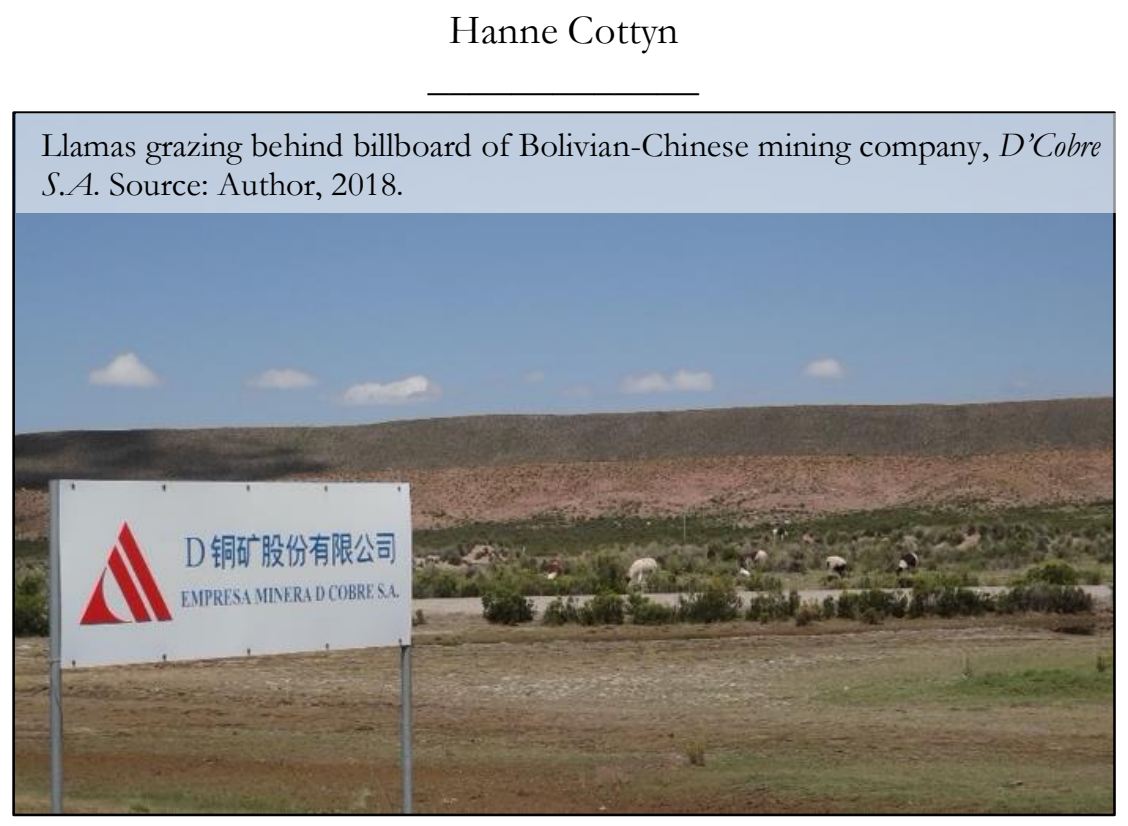

Keywords: Bolivia, copper mining, llamas, Covid, Indigenous communities

A long the brand-new highway crossing the Bolivian high plateau towards the Chilean border, only a shiny ChineseSpanish billboard signals the reappearance of an old copper frontier on the border of two indigenous communities. Turco and Choquecota are neighbouring communities that belong to the native nation of Jach'a Karangas, a federation of Aymara communities, Bolivia's second largest ethnic population. Situated within the department of Oruro, Jach'a Karangas comprises the highland plains between the Bolivian-Chilean border and Lake Poopó.
During a visit to the copper mine in March 2018, I met don Cupertino, a man in his sixties living next to the administrative offices of the Bolivian-Chinese company "D'Cobre" which currently exploits the site. Along the dusty sand path from the highway towards his house, a rusty and damaged signboard reading "Cuprita" (literally cuprite, a cuprous oxide mineral) hints at a longer copper history. Just as numerous other remote sites that developed into tributary arteries of a globalizing mining sector, the memory of local communities often constitutes our main

\section{Correspondence:}

Hanne Cottyn, hanne.cottyn@.york.ac.uk

Cite this article:

Cottyn, H. 2020. "Copper, Llammas and a Virus: A Tale of Historically Entangled Frontiers." Commodity Frontiers 1: 16-21. doi: 10.18174/CF.2020a17966.

Commodity Frontiers is an open-access journal edited by the CFI Editorial Board, Mindi Schneider, senior editor. Read it online at Commodity Frontiers, or our website, commodityfrontiers.com.

This work is licensed under a Creative Commons Attribution-NonCommercial 4.0 International License. 
source to reconstruct their overlooked history.

The llamas grazing behind the new billboard seem to offer a contrasting sight, one of a traditional pastoralist world literally pushed into the background by a new regime of mineral extraction. However, it is a misleading sight. In fact, the local camelid economy is emerging as a new frontier. Where minerals and llamas were once in some way allied protagonists in the rise of capitalism, they now compete in the same space, although on different scales. This essay reflects on my re-encounter with the llama herders of Turco and their entanglement with histories of capitalism and indigenous resistance (after many years without visiting). The pandemic sheds a new light on these shifting entanglements. ${ }^{2}$

\section{eappearing mineral frontiers -
"it is a bit very uncomfortable"}

Copper and China are two key factors that have been pushing global mineral frontiers over the last decades. Considered as the world's most important industrial metal, global copper mine production has experienced a steady growth, supported in part by a strong demand from China. A consumer of half the world's copper output, China has become progressively more invested in foreign reserves of the metal. This trend is particularly evident in Latin America. China's copper supply relies heavily on South America, with particularly large investments in Peru and Chile. ${ }^{3}$ Bolivia, caught between the two countries, remains a small player in the copper industry. Yet, in a context of rising resource security challenges, a relatively sound copper market, and new technologies, mining is re-appropriating marginal and abandoned frontier spaces.

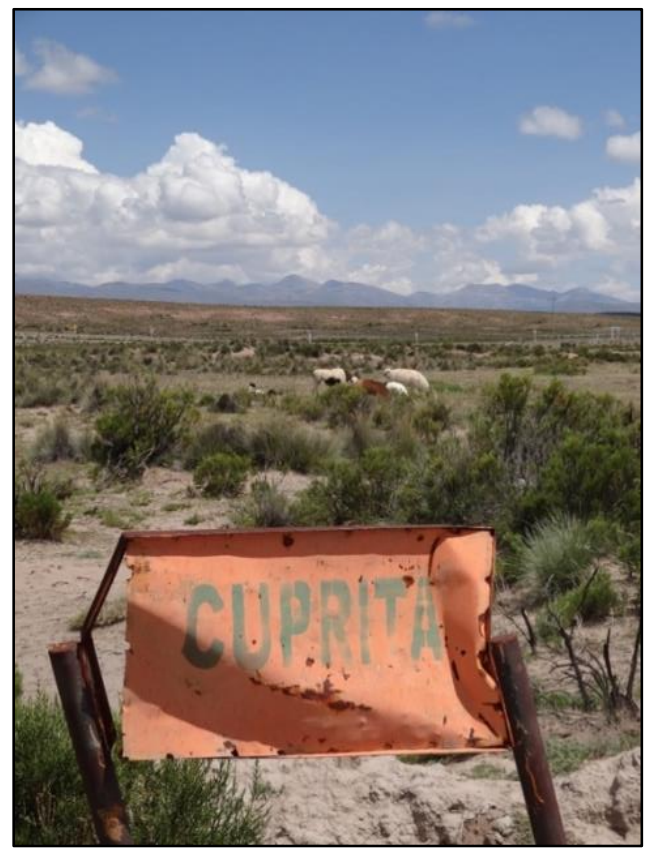

Llamas grazing behind the old signboard of the "Cuprita" copper mine. Source: Author, 2018.

One of those spaces is located in the Central Andean highlands, in Cupertino's home community of Turco. "I am a native of this land and precisely with me the company has grown, because I have worked in the company before," Cupertino told us. ${ }^{4}$ According to local collective memory, mining arrived to this community with the Spanish, although the area has traces of Inca mining. Later on, in the early $20^{\text {th }}$ century, Cupertino's parents told him of the presence of the powerful Aramayo family. Possibly, the site became part of the operations of the "Aramayo Franke \& Cía Ltd." in hands of Carlos Víctor Aramayo, dedicated to silver, tin, copper and other minerals. ${ }^{5}$ However, during the national revolution of 1952, around the time Cupertino was born, the

\footnotetext{
${ }^{2}$ This reflection came out of a collaboration with Julián Arias Carballo and Norma Mollo Mollo from the NGO Centro de Ecología y Pueblos Andinos in Oruro, Bolivia. I also wish to thank don Cupertino ${ }^{2}$ and Mr. Gang for their testimonies.

3 Vasquez, Patricia I., David Humphreys and Ana Elizabeth Bastida. 2018. "China's engagement in the mineral sector in Latin America: Lessons learned and opportunities for international cooperation," European Policy Brief Strategic Dialogue on
}

Sustainable Raw Materials for Europe (STRADE), No. 08.

${ }^{4}$ Interview with Mr. Cupertino, by the author and Norma Mollo Mollo. Turco, 15 March 2018.

5 Peñaranda Subieta, Jaime. 1996. Who is who? En la minería boliviana, Documento de Trabajo, No. 01/96. La Paz: Universidad Católica Boliviana, Instituto de Investigaciones Socio-Económicas (IISEC), 4. 


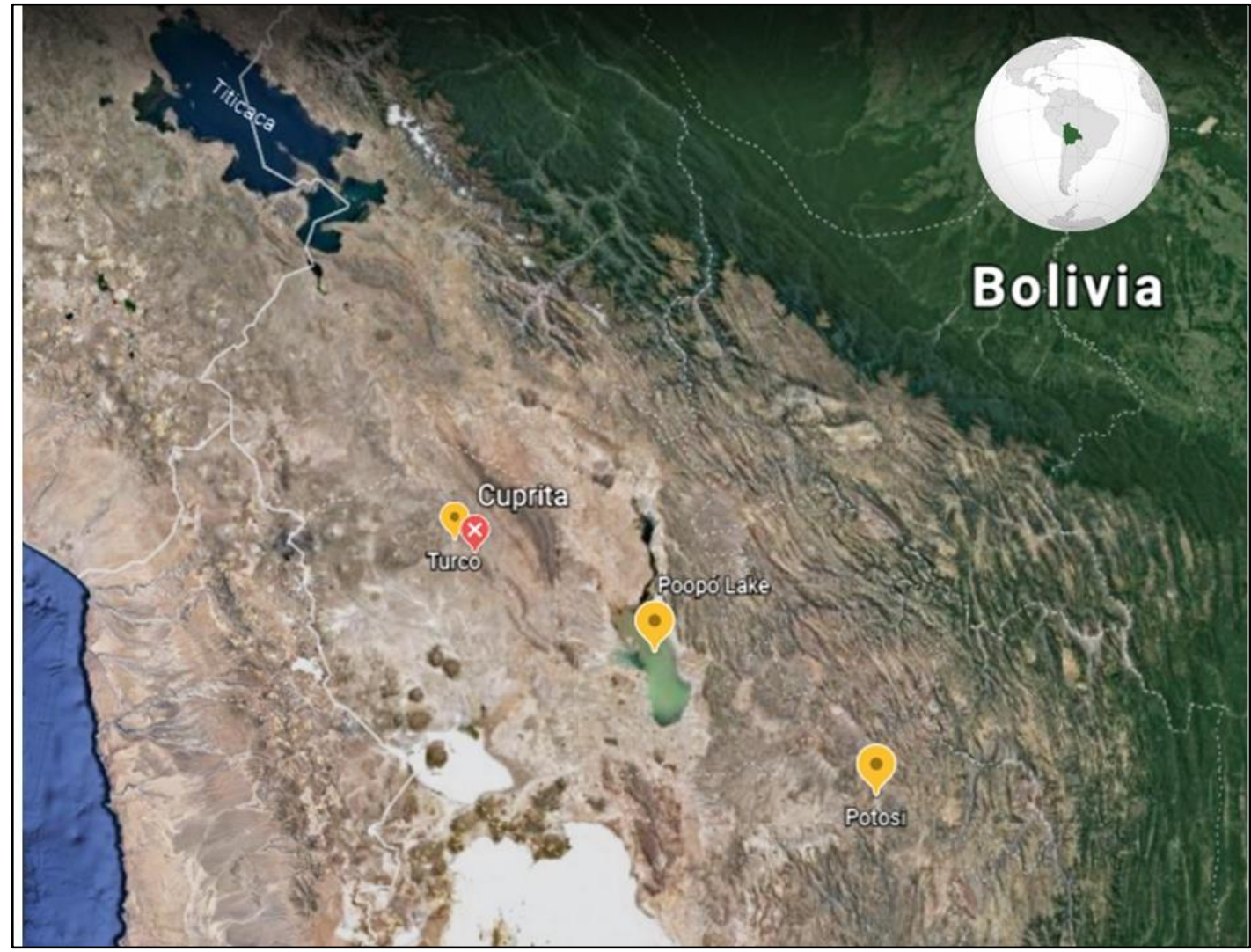

Localization of the Cuprita mine. Adaptation of Google

Earth image by the Author.

Bolivian government nationalized the mining operations of the country's dominant mining families, the so-called "tin barons" Patiño, Hochshild and Aramayo.

Relying on his own childhood memories, Cupertino reconstructs a fluctuating history of rudimentary and mostly failed attempts of turning "Cuprita" into a successful copper exploitation. He remembers how Max Biggeman, of German descent, became owner of the site in the 1950s; his family would keep this property until around 2005. Biggeman worked successively with a US Company named "Murillo", the Japanese Mitsubishi, and a Yugoslav operation, yet by 1975, the National Council of Agrarian Reform reported that the "comfortable constructions" of the Cuprita mine's administrative office had been abandoned. ${ }^{6}$ In 1988, a Chilean company tried to set up its operations, followed by another US company called "Discovery", and then a French company in the 1990s. Biggeman eventually gave up and decided to turn the offices into a hotel in 1999, which was closed in 2003. Biggeman's children wanted to continue the copper exploitation but their unstable financial situation led them to sell to the current Chinese operators, according to Cupertino. The company acquired legal presence by 2013, starting operations in 2016.

To Cupertino, having witnessed mining entrepreneurs removing sand and stones for decades at his doorstep, his terrain now seemed to have been "swallowed" by a copper mine of much larger proportions. The pickaxes and basic machinery have been replaced by open pit technologies, which involves perforation and detonation techniques to remove enormous amounts of waste rock. The former Azurita and Cuprita

\footnotetext{
${ }^{6}$ Brigadas móviles de CNRA, 20 September 1975,

Ayllu Jilanaca, sección Llallagua. Archives of INRA

Oruro, Turco Marka, Cuerpo 5.
} 
mines have been absorbed, and expanded with "Cuprita II", an open pit project in the hands of the Bolivian company D'Cobre S.A. D'Cobre belongs to the Chinese company Chihong Zinc \& Ge, which is part of the Yunnan Metallurgical Group Co. Ltd. During our visit to the mine's processing plant, a Chinese banner at the site proudly stated that Yunnan Metallurgical Group represented a "green and low-carbon industry" and labelled Chihong as a pioneer in "circular economy pilot enterprises in China."

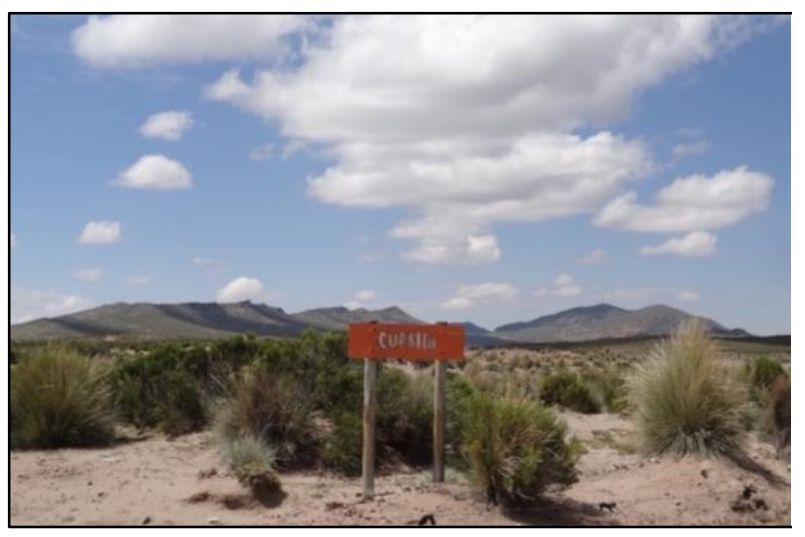

Old signboard of the "Cuprita" copper mine. Source: Author, 2018.

When interviewing the current Chinese manager at the site, he underlined that "this form of mining means respect for the environment." 8 "Responsible, how?!" was don Cupertino's reaction afterwards, when told of the Chinese claims. Cupertino recalls how his community was still a green space in the late 1950s. Yet,

last year there was a drought and my animals have died, not only mine but those of several others too. Now those effects of dynamite what do I know, the fumes ... Aww, it's impossible. Every day there are explosions. ... Every day about 40, 50 shots, something like that. They are breaking up the earth every day. Now, when I come with my llamas, it is a bit very [sic] uncomfortable ... The llama is an animal and when it must eat, it wants to be calm. So, the llama feels half wrecked, and catches disease.

Cupertino now regrets that they, as a community, never opposed the mining operations, in the past and more recently. Over time, they have let these miners successively invade their lands and displace them. "In those times, they entered our [lands], they have discriminated us a little ... totally." When the Chines arrived, his community just agreed, in order not to cause problems or risk the total closure of the mine. Yet, "that's what we needed [to have done], close [the mine] definitely," Cupertino laments today.

\section{n emerging llama frontier \\ 1 The way in which llamas define} production and trade patterns, local culture and identity in pastoralist communities such as Turco and its neighbours cannot be overstated. "To understand our history, you need to understand our llamas" I've learned from Jach'a Karangas' indigenous leaders. The region is recognized as Bolivia's epicentre and world leader in organic llama breeding and meat production, particularly of "charque" or jerked llama meat. Turco, which has been awarded the title of "Bolivia's capital of South-American camelids", is working hard to turn the llama into a success story. While charque is an ancestral practice still marked by a rudimentary level of technology, its production has received a boost since the 1980s. Contemporary llama meat producers still recall how popular urban belief rejected charque as "unfit for human consumption" and laws prohibited its commercialization in the city. ${ }^{9}$

In urban eyes, the label of "human consumption" did not apply to indigenous people, who remained excluded from formal citizenship until the middle of the $20^{\text {th }}$ century and continued to be harshly discriminated. Charque only got rid of the

\footnotetext{
7 Fragment of a banner by Yunnan Metallurgical Group Co. Ltd. Translation facilitated by CATAPA vzw.
} 
stigma by the late $20^{\text {th }}$ century when it started to enter the national market. The Programme for Peasant Self-development (PAC-Oruro, 1983-1997) -supported by the European Economic Community- was key in promoting llama meat, highlighting its high protein value and nearly zero cholesterol. Pastoralists began to organize in cooperatives to distribute the camelid meat they have been producing and processing for centuries across the country and beyond. Today, the dried llama meat is mainly commercialized through the supermarkets of Bolivia's major cities.

\section{$\uparrow \begin{aligned} & \text { o llamas, no minerals, no } \\ & \text { capitalism }\end{aligned}$}

Copper entering llamaland therefore appears as the tale of a strong global frontier displacing an emerging indigenous frontier. A tale of minerals dictating the rhythm of global capitalism and suffocating local economies. However, this is an area with a long and deep history of mining - in which llamas used to play a starring role. In contrast to the typical representation of indigenous pastoralist societies as isolated, un-innovative and static, camelid-based communities, like those I encountered in Jach'a Karangas, have successfully linked up to regional commodity markets. Meanwhile, their pasture lands, unfit for cultivation, remained out of the scope of land enclosure processes.

The same was true in the past. The exploitation of the Cerro Rico -"the rich mountain"- of Potosí, for example, constituted the structuring force behind the emergence of a capitalist world-economy. As Jason W. Moore writes, the developments in and around Potosí laid the groundwork for $17^{\text {th }}$ century money capital-formation with worldwide reverberations. ${ }^{10}$ But the mountains of silver that financed Europe's wars would have never left Potosí if it were not for the llamas of Jach'a Karangas -then incorporated as the colonial province of Carangas. The region was not only the site of colonial mines that contributed to the Spanish Royal Treasury, but also home to vast herds of llamas which were mobilized in caravans between Potosí and the ports of the Pacific. Carangas was strategically situated on the "silver route" along which precious metals and essential mining supplies such as salt, wood and mercury were transported.

In the rise of global capitalism, then, Andean camelids mobilized the mining frontier. Both mining and llamas are intrinsically part of Jach'a Karangas, yet llamas' relation to mining has changed. The decay of the Potosí mining economy in late colonial times was followed by $19^{\text {th }}$ century technological changes that reduced the role of llama caravans to that of indigenous long-distance barter exchange. Llamas continue to enter the market, yet no longer as beasts of burden nor in connection to the mining economy, but as meat for tourist and urban household consumption. Small-scale rudimentary mining became industrialized open pit mining; extracted minerals are transported on trucks and cargo ships towards China. Mineral frontiers move faster, suddenly reappear in marginal corners, and plan to leave within a decade or two. As Cupertino reflects: "Their aim is, well, to personally carry out the exploitation and then leave, because they are not interested in history."

The growing llama economy informs local communities' stance towards the new mining operations appearing in their territories. An extensive literature review on why and how local communities across continents resist mining "suggests that communities are more likely to resist when they are able to perceive a threat to their health or livelihood."11 While boosting local identity and pride, they are substituting the promises of copper mining. Hence, indigenous leaders are framing the copper mine in terms of its potential impact
10 Moore, Jason W. 2010. "This lofty mountain of
silver could conquer the whole world": Potosí and
the political ecology of underdevelopment, 15451800', The Journal of Philosophical Economics, 4 (1): 59.
${ }^{11}$ Conde, Marta. 2017. "Resistance to Mining. A Review." Ecological Economics: The Journal of the International Society for Ecological Economics 132 (February): 81-82. 
on the rise of their llama market leadership. Supported by local institutions, they have started to visit other mining sites to gain insight in the ways mining relates to pastoralist activities and the scaling up of meat production. The emergence of llamas as a viable alternative -and no longer an adjunctto mining offers a source for resistance.

\section{The virus as a window on entangled frontiers - magnifying glass or blindfold?}

In late 2019, the indigenous authorities of Jach'a Karangas adopted the principle of "Zero Mining" in their territories. However, the lack of transparency on the part of the mining company and the indigenous leadership's shifting political loyalty has prevented any concrete action in that direction. Indigenous authorities tend to pragmatically navigate Bolivia's political landscape -in which all major players continue to heavily promote extractive sectors. On top of the political turmoil since November 2019 and the current pre-electoral atmosphere came COVID-19. The virus has hit the region hard. Jach'a Karangas has lost some of its key indigenous leaders to the virus, seriously affecting its capacity to respond to the political and sanitary crisis, let alone the impact of mining in its territory.

Oruro, the capital city of the department within which Jach'a Karangas is situated, was the first in Bolivia to go in lockdown, on March 31 ${ }^{\text {st }}$ 2020. With strict confinement measures in place, Oruro never experienced shortages in the food supply during the following months. Family agriculture, including the production of llama meat, played a key role in keeping up food provisions at the departmental level. It offers the cooperative- or family-based llama sector ammunition in defending family agriculture against the national government's reliance on an agribusiness model, represented by large landowners in the eastern lowlands.

Little by little, the government -with support by the International Fund for Agricultural Development (IFAD)- now appears to be willing to incentivize local production such as charque as a strategy to feed the population and to reactivate the economy. At the same time, large mining operations across the country are paralyzed, jeopardizing local, regional and national governments' social programmes, which importantly rely on revenues from mining. While the coronavirus crisis accentuates the vulnerability of the country's extractive policies, it helps to unveil the historical indifference towards family agriculture and seems to open room for Turco's llama economy.

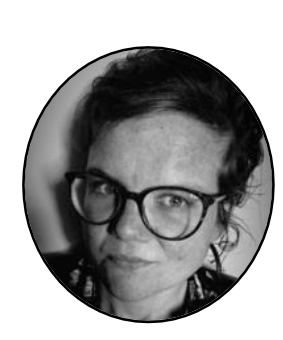

Hanne Cottyn is a postdoctoral researcher at the Department of History, University of York (UK). Her research focuses on rural communities, land and socio-environmental conflicts, and landscape transformations in the Andean region. She is an affiliated to the Interdisciplinary Global Development Centre (University of York, UK), the Research Group Economies, Comparisons, Connections (Ghent University, Belgium), and an active member of CATAPA and the Belgian Latin America network ENCUENTRO. 